\title{
НАРОДНА КУЛЬТУРА УКРАЇНИ ЯК ВАЖЛИВИЙ СКЛАДНИК ПРОФЕСІЙНОӤ ПІДГОТОВКИ СПЕЦІАЛІСТІВ МЕДІАДИЗАЙНУ
}

\author{
Рябченко О. М. \\ викладач \\ КЗВО «Хортицька національна навчально-реабілітаційна академія» \\ Запорізької обласної ради \\ вул. Наукового містечка, 59, Запоріжжя, Украӥна \\ orcid.org/0000-0002-8488-846X \\ matros6410@gmail.com
}

\author{
Ключові слова: культурна \\ спадиина, медіапростір, \\ творчий проиес, медіадизайн, \\ творча молодь.
}

\begin{abstract}
Метою статті $є$ обгрунтування значущості використання народної культурної спадщини та народних традицій під час навчання медіадизайнерів та виховання творчої молоді в дусі патріотизму. Статтю присвячено питанню фахової підготовки медіадизайнерів у контексті вивчення культурної спадщини українського народу, застосування народних культурних надбань для втілення у сучасних дизайн-проєктах. Розглянуто влив народної культури на становлення творчої особистості в сучасному мистецтві та під час підготовки фахівців творчих професій. Проаналізовано стан розвитку культурного складника сучасного навчального процесу та заходи для поліпшення професійного та духовного рівня дизайнерів. Виявлено дефіцит знання власної культури серед творчої молоді ще до процесу фахової підготовки через брак інформації про власну культуру та народні традиції, нехтування важливістю цього складника або неправдивість чи викривлення цієї інформації. Відродження інтересу до культури власного народу заохочує дизайнерів використовувати творчі, культурні надбання у власних проєктах.

3'ясовано, що існує творчий інтерес до народної культури України серед молодих митців сучасності, що доводить важливість творчого зв'язку поколінь, де духовність $є$ вирішальним чинником культурного середовища, сприяє створенню медіапростору, що відповідає високим моральним принципам та формуванню здорового художнього смаку. Результатом дослідження процесу фахової підготовки $є$ актуальність поєднання професійного складника фахівців медіадизайну зі знанням народної культури та культурної спадщини українського народу під час навчального процесу. Застосування сучасних можливостей спрямовуються на поглиблення знань власної культури, підвищення вимог до творчих завдань у контексті відповідності моральним принципам на основі вивчення культурної спадщини українського народу. Доведено, що розуміння народного мистецтва, застосування культурних надбань, користування народною спадщиною забезпечують високі творчі досягнення під час фахової підготовки та відповідальне ставлення до дизайн-проєктів.
\end{abstract}




\title{
FOLK CULTURE OF UKRAINE AS AN IMPORTANT COMPONENT OF PROFESSIONAL TRAINING OF MEDIA DESIGN SPECIALISTS
}

\author{
Ryabchenko O. M. \\ Teacher \\ Municipal Institution of Higher Education «Khortytsia National Educational and Rehabilitational \\ Academy» of Zaporizhzhia Regional Council \\ Naukove mistechko str., 59, Zaporizhzhia, Ukraine \\ orcid.org/0000-0002-8488-846X \\ matros6410@gmail.com
}

Key words: cultural heritage, media space, creative process, media design, creative youth.
The purpose of the article is to substantiate the importance of using folk cultural heritage and folk traditions in the training of media designers and education of creative youth in the spirit of patriotism. The article is devoted to the issue of professional training of media designers in the context of studying the cultural heritage of the Ukrainian people, the use of folk cultural heritage for implementation in modern design projects. The article considers the influence of folk culture on the formation of creative personality in contemporary art and during the training of creative professions.

The state of development of the cultural component of the modern educational process and measures to improve the professional and spiritual level of designers are analyzed. There is a lack of knowledge of their own culture among creative youth before the process of professional training due to lack of information about their own culture and folk traditions, neglect of the importance of this component, or when this information is untrue or distorted. The revival of interest in the culture of their own people encourages designers to use creative, cultural heritage in their own projects.

It was found that there is a creative interest in the folk culture of Ukraine among young contemporary artists, which proves the importance of creative connection between generations. Spirituality is a decisive factor in the cultural environment, contributes to the creation of a media space that meets high moral principles and the formation of healthy artistic taste. The result of the study of the process of professional training is the relevance of combining the professional component of media design specialists with knowledge of folk culture and cultural heritage of the Ukrainian people during the educational process. The use of modern opportunities is aimed at deepening the knowledge of their own culture, increasing the requirements for creative tasks in the context of responsibility for moral principles based on the study of the cultural heritage of the Ukrainian people. It is proved that the understanding of folk art, the use of cultural heritage, the use of folk heritage provides high creative achievements during professional training and a responsible attitude to design projects.
Найдорожчим скарбом будь-якого народу $\epsilon$ культурна спадщина, творчі надбання та мудрість саме цього народу. Реалізація творчих проєктів, художніх задумів у сучасному суспільстві передбачає тісний зв'язок, глибоке знання та глибоке розуміння народної культури. Мистецтво покликане точно, чисто та щиро віддзеркалювати реальність та виявляти прагнення до високої духовності, до свободи, до правдивості, надихаючи сучасних митців продовжувати народні традиції, збагачувати творче надбання свого народу. Тема зв'язку поколінь $\epsilon$ актуальною в сучасному суспільстві та важливою в мистецтві, яке покликане віддзеркалювати художню правду, духовний стан та головні прагнення людей.

Задля успішності навчального процесу підготовки фахівців творчих професій важливим $€$ духовний та культурний рівень студентів, який досягається завдяки глибокому аналізу культурної, духовної, а також історичної спадщини українського народу. Навчальний процес формує творчу особистість, спираючись на актуальність 
упровадження культурної спадщини в повсякденне життя людей. Митець завжди був і є відповідальною особистістю, яка надихає суспільство на добрі духовні справи, а ще нагадує про головні цінності, якими є воля, віра, родина, рідна земля.

Культурний зв'язок поколінь стає конче важливою ланкою в процесі становлення творчої особистості. Справжнє натхнення є там, де щирість та небайдужість до теми творів є головними художніми принципами. Про важливість упровадження культурної спадщини українського народу та знання народної культури, виховуючи сучасну творчу молодь, свідчать численні сучасні публікації Н. Кондель-Пермінової, А. Коник, С. Берегового, Н. Шарати, Н. Пальм, Т. Гетало та ін. Мобільність інформаційних джерел сьогодні сприяє швидкому обміну творчими надбаннями та ідеями стосовно сучасного буття та культурних подій.

Культурна та духовна спадщина народу України дуже цікавила багатьох видатних українських науковців та громадських діячів (Д.І. Яворницький, М.С. Грушевський, I.I. Огієнко). I.I. Огієнко здійснив переклад Святого Письма українською мовою 3 давньоєврейської й грецької мов. Освітянин, історик, громадський діяч, мовознавець, церковний діяч жив щирою любов'ю до рідної землі, рідної мови, української Церкви. Тема духовного виховання як основи навчального процесу залишалася головною протягом усього життя Івана Огієнка. Він уважав, що виховання молоді $\epsilon$ пріоритетним, тому що саме молодь формує майбутнє свого народу та є носієм народної культурної спадщини. Ця тема не втрачає актуальності й сьогодні [1, с. 99].

Історичні дослідження Д.І. Яворницького дають нам можливість зануритися у славні часи Запорозької Січі та познайомитися зі звичаями, культурою та укладом життя козаків-запорожців. Воля, рідна земля, родина, віра - це є головні цінності українського народу.

Метою статті $\epsilon$ обгрунтування значущості використання народної культурної спадщини та народних традицій під час навчання спеціалістів медіадизайну та виховання творчої молоді в дусі патріотизму. Правдиве відображення дійсності є обов'язковим складником живого, цікавого, художньо-цінного, життездатного мистецтва. Сучасність дає людству нові форми самовираження. Медіапростір широко використовується для поширення сучасних творчих ідей, спрямувань, дає можливість мобільного огляду творчих тенденцій сучасного мистецтва, надихає на нові креативні пошуки. Але, на жаль, не всі проєкти, художні твори, перформанси та форми вираження ідей відповідають моральним принципам та етичним засадам, що змушує пильно ставитися до сучасних подій у світі мистецтва.
Сучасне мистецтво України формується залежно від рівня духовності митців, їх вихованості на культурних традиціях, відповідального ставлення до творчості, відданості справі та любові до свого народу. Медіапростір певною мірою впливає на формування світогляду людей, їх ставлення до сучасних подій, душевному стану. Мобільність інформаційних джерел сьогодні сприяє швидкому обміну творчими надбаннями та ідеями стосовно сучасного буття та культурних подій. Дизайнери, у тому числі ті, хто формує цей простір, мусять відповідати високим духовним вимогам, розуміючи важливість упровадження правдивості матеріалу та відповідність його якості та художньої цінності. Сьогодні підготовка медіадизайнерів $є$ пріоритетною через виклики сьогодення, які пов'язані 3 масовим поширенням неправдивої інформації та хибними коментарями про події в суспільстві та світі мистецтва, відсутністю художнього смаку (а інколи відвертою непристойністю) через непрофесійність. І це явище є викликом для суспільства та представників творчих професій, які покликані впроваджувати високу моральність та художній смак у життєвий простір.

Варто відзначити існування дефіциту знання власної культури серед творчої молоді ще до процесу фахової підготовки через брак інформації про власну культуру та народні традиції або неправдивість чи викривлення цієї інформації. Саме тому виховання та навчання творчої молоді повинні базуватися на знанні власної культури, духовності та вірі. Культурна спадщина є потужним потенціалом для творчої молоді та підставою бути гідними провідниками надбань та мудрості минулих поколінь, усвідомлюючи себе важливою ланкою процесу, який має назву «історія власного народу». Базування навчального процесу на принципах духовного виховання та високої моралі $\epsilon$ запорукою здорового мистецтва, чистого від прагнення здивувати за будь-яку ціну, що часто веде до розбещення глядачів або користувачів подібних сайтів та інформаційних джерел. Саме тому формування здорової творчої особистості, яка вихована на знанні власної культури та історії, стоїть на першому місці та $є$ конче важливою задля чистоти культурного та інформаційного простору, яким користуються студенти. Будь-яка творча робота митців сприяє формуванню художнього смаку у глядача чи користувача продукцією дизайнерів, у яких, своєю чергою, був він вихованим.

Джерелом натхнення творчої молоді сьогодні стає непередбачуваність сучасного ритму життя, нові форми та напрями в мистецтві, можливість знайти власний творчий шлях та винайти абсолютно новий жанр, в якому проявити свою індивідуальність оригінально стає головною метою творчих пошуків. Але без знання творчої спадщини 
минулих поколінь, фольклору, рідної мови, народних традицій та цінностей, історії власного народу творчий продукт стає безликим та поверхневим через відсутність народного коріння та змістовної глибини, яка $є$ в народній творчості. Знання творчого коріння свого народу сприяє натхненню сучасних митців та є невичерпним джерелом творчості.

Народне мистецтво сповнене історичної та художньої правди, і саме цьому принципу слід навчатися творчій молоді, досліджуючи невичерпне джерело творчого спадку українського народу. Виховуючи любов до рідного краю, сучасна скарбниця творчості збагачується щирими, цікавими творами мистецтва. Про творчий зв'язок поколінь та важливість розвитку мистецтва на основі творчих надбань минулих часів свідчить наявність народних традицій у сучасному мистецтві та житті українського народу. Носіями народної культури, історичної пам'яті є українська мова, народні перекази, легенди та міфи, фольклор, літературна спадщина, образотворче та декоративно-прикладне мистецтво. Усі ці чинники сприяють формуванню у творчої молоді самоідентичності та культурної приналежності до активного творчого життя в сучасному світі мистецтва.

Навчальний процес, який базується на вихованні у студентів насамперед людяності та відповідального ставлення до творчого процесу, завжди $\epsilon$ важливим. Небайдужість до майбутнього рідного краю $є$ запорукою щирого, відповідального ставлення митців до власної творчості, бажання глибокого знання історії та культури України задля продовження творчих традицій, збагачуючи їх власними досягненнями в мистецтві та дизайні. Під час навчального процесу важливу роль відіграє робота 3 аналогічними матеріалами, що суттєво впливає на формування творчої особистості. Саме тому важливо спрямовувати студентів до достойного уваги робочого матеріалу, який допомагає підвищувати не лише професійний рівень студента, а й впливає на формування вихованої, високодуховної, самодостатньої, професійно впевненої творчої особистості, здатної створювати нові творчі проєкти, які свого часу стануть достойними аналогами для прийдешніх поколінь митців.

Уміння креативно мислити, створюючи проєкт, в якому простежується надбання минулих поколінь та культурні традиції українського народу, $\epsilon$ свідченням успіху навчального процесу. У процесі підготовки медіадизайнерів важливим аспектом $\epsilon$ виховання вміння працювати самостійно, використовуючи власне бачення, але через призму культурних традицій та художньої правди, створюючи естетичний проєкт, спрямований зацікавити своєю ідеєю, виразною подачею. Культурна спадщина українського народу багата народною мудрістю, ідеями, які варті уваги сьо- годні продовжити їх утілювати, бо вони актуальні, вони життєздатні. Це - любов до рідної землі, до власного народу, культура якого надихає сучасних авторів продовжувати культурні традиції українського мистецтва. Творчий процес вимагає глибокого розуміння теми проєкту, власного бачення та розуміння цієї теми для послідовної роботи, аналізуючи всі можливі варіанти втілення кінцевої ідеї.

Навчальний процес, ураховуючи вимоги сучасного ритму життя, базується на високих моральних, духовних та професійних принципах творчої молоді, іiі громадської та творчої активності в житті своєї країни. Сьогодні ми є свідками відродження культури України, їі історичного місця у світовій культурі. Важко усвідомлювати факт того, що тривалий час культура, мова українського народу були під загрозою знищення, але сьогодні відповідальність за Україну та їі культуру стає головним завданням нинішнього покоління.

Якісне, живе мистецтво, духовно здоровий медіапростір, патріотична література та всі творчі жанри стають запорукою нового мистецтва України, життєздатного, вихованого на народних традиціях та любові до рідної землі. Сучасна творча молодь покликана формувати нове мистецтво відродженої, вільної країни, продовжувати традиції, збагачуючи творчий спадок, відкриваючи творчий шлях прийдешнім поколінням. Інвестиція в навчальний процес творчої молоді приречена на успіх, тому що творчі проєкти впливають на світогляд пересічних людей, формують їхню самоідентичність. Важливими умовами якості творчої продукції $\epsilon$ щира правда та любов, духовне наповнення твору, без якого робота буває неживою та нецікавою.

Отже, результатом дослідження процесу професійної підготовки $€$ актуальність поєднань фахового складника спеціалістів медіадизайну зі знанням народної культури та культурної спадщини українського народу під час навчального процесу. Ставлення до виховання людяності та духовності разом із навчанням професійним навичкам творчої молоді, іï вмінню відповідально ставитись до роботи, бути носіями художнього смаку $є$ сьогодні пріоритетом навчального процесу. Знання та розуміння народного мистецтва, застосування культурних надбань, користування народною спадщиною є запорукою успіху у фаховій підготовці медіадизайнерів та відповідального ставлення до творчих проєктів. Уміння послідовно вести роботу над творчим проєктом, користуючись творчим спадком українського народу, традиціями народного мистецтва, забезпечує цікавий результат, який буде зрозумілим та по-справжньому цінним через художню правдивість. Творче життя вимагає постійного вдосконалення професійності, духовного стану та правдивого бачення дійсності, яка надихає на нові творчі задуми. 


\section{ЛІТЕРАТУРА}

1. Огієнко I.I. Українська культура. Коротка історія культурного життя українського народу. Київ, $1991.272 \mathrm{c}$.

2. Титова О.М. Деякі актуальні питання збереження культурної спадщини України. Пращі Центру пам'яткознавства. 2009. Вип. 16. С. 5-10.

3. Білокінь С.І. Довідкова книга 3 культурної спадщини України : метабібліогр., зміст біогр. та ін. словників тощо : робочий зошит ; НАН України, Центр культуролог. студій Ін-ту історії України. Київ : Ін-т історії України, 2009. 514 с.

\section{REFERENCES}

1. Ogienko, I.I. (1991). Ukrainian culture. A brief history of the cultural life of the Ukrainian people. Kyiv.

2. Titova, O.M. (2009). Some topical issues of preserving the cultural heritage of Ukraine. Proceedings if the Center for Monument Studies. Vol. 16. Pp. 5-10.

3. Bilokin, S.I. (2009). Reference book on the cultural heritage of Ukraine: metabibliogr., The cjntent of biogr. etc. dictionaries, etc : workbook / SI Bilokin; NAS of Ukraine, Center for Cultural Studies. studies of the Institute of History of Ukraine. Kyiv : [Inst. Of History of Ukraine]. 514 p. (Series "Sources for cultural studies"; issues 4-7). 